\title{
AVOIN TOIMINTAKULTTUURI VAHVISTUU AMMATTIKORKEAKOULUISSA
}

\author{
Viime vuosien aikana on käyty paljon keskustelua \\ tutkimuksen yhteiskunnallisesta näkyvyydestä. On tärkeää \\ saada tutkimushankkeissa syntyneet tulokset ja osaaminen \\ hyödynnettäviksi myös korkeakoulujen ulkopuolelle sekä \\ päätöksenteon tueksi että työ- ja elinkeinoelämän käyttöön. \\ Tiedonkulkua ja näkyvyyttä voidaan parantaa mahdollisimman \\ avoimilla toimintatavoilla. Avoimen tieteen ja tutkimuksen \\ toimintamallien avulla tutkimuksen vaikuttavuutta voidaan \\ lisätä niin tiedeyhteisön sisällä kuin sen ulkopuolellakin.
}

A voimen tieteen ja tutkimuksen sijasta ammattikorkeakouluissa puhutaan avoimesta tutkimus-, kehittämis- ja innovaatiotoiminnasta (TKI). Sillä pyritään ensisijaisesti edistämään työ- ja elinkeinoelämäyhteistyötä ja edesauttamaan tiedon ja osaamisen virtausta ammattikorkeakoulujen innovaatioekosysteemeissä. Avoin TKI-toiminta koostuu samoista osa-alueista kuin avoin tiede ja tutkimus, mutta avoimuuden toteuttamisen tavoissa on eroja, mikä näkyy esimerkiksi julkaisutoiminnassa. Sen lisäksi, että ammattikorkeakoulut tavoittelevat tiedejulkaisujen avoimuutta, myös ammatillisten ja suurelle yleisölle suunnattujen julkaisujen avoimuus on tärkeää.

Opetus- ja kulttuuriministeriö (окм) on arvioinut korkeakoulujen avoimuuden tasoa ja tilannekuvaa jo kahdesti (Avoin tiede ja tutkimus -hanke, 2015 ; Open Science and Research Initiative, 2016). Arviointi on koh- distunut korkeakoulujen strategiseen ohjaukseen, politiikoihin ja periaatteisiin, avoimuuden tukemiseen sekä osaamisen vahvistamiseen. Tarkastelun perusteella organisaatiot on pisteytetty ja sijoitettu viisiportaiselle asteikolle avoimen toimintakulttuurin kehittyneisyyden mukaan.

Kypsyystason ensimmäisessä selvityksessä ammattikorkeakoulut menestyivät melko huonosti ja sijoittuivat arviointiasteikon alimmille portaille eli tasoille yksi ja kaksi. Toisessa arvioinnissa suurin osa ammattikorkeakouluista sijoittui jo tasoille kaksi tai kolme. Yksikään ammattikorkeakoulu ei vielä päässyt portaikon ylimmälle tasolle, jolle tosin yliopistoistakin ylsi vain Helsingin yliopisto. Arviointien tulokset olivat ammattikorkeakoulujen osalta odotettuja, sillä selvitysten aikoihin avoimen toimintakulttuurin luominen ja sen tukemiseen tarkoitettujen toimintamallien kehittäminen oli vasta aluillaan (ks. myös Päällysaho \& Latvanen 20I8). 


\section{Avoimen toimintakulttuurin kehittämistä yhteistyössä}

Kypsyystasoselvitykset ovat tarjonneet hyvän lähtökohdan ammattikorkeakoulujen avoimen TKI-toiminnan kehittämiseen. Sitä

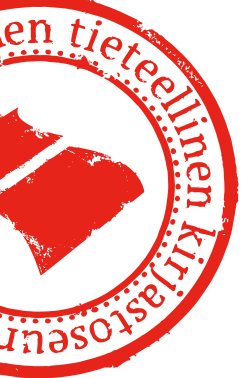
on kehitetty muun muassa yhteisten hankkeiden avulla sekä yhteistyössä yliopistojen ja avoimen tieteen ja tutkimuksen valtakunnallisten toimijoiden kanssa.

Avoimen toimintakulttuurin perustaa luotiin vuosina 20 I 5-20I7 hankkeessa nimeltä Avoimuuden lisääminen korkeakoulujen käyttäjälähtöisessä innovaatioekosysteemissä. Kyseisen hankkeen aikana edistettiin etenkin ammattikorkeakoulujen tietoisuutta avoimista toimintatavoista ja pyrittiin luomaan yhteistä tahtotilaa niiden käyttöönottoon. Työskentely sai jatkoa vuoden 2018 keväällä käynnistyneessä OKM:n rahoittamassa korkeakoulutuksen kärkihankkeessa Ammattikorkeakoulujen avoin TKI, oppiminen \& innovaatioekosysteemi. Hankkeessa on mukana I I ammattikorkeakoulua ja yksi yliopisto ja sitä koordinoi Seinäjoen ammattikorkeakoulu.

Meneillään olevan hankkeen päämääränä on edelleen vahvistaa avoimen TKI-toiminnan vaatimaa osaamista ja infrastruktuuria. Yksi konkreettisista tavoitteista on saada aikaan ammattikorkeakoulujen yhteinen tukipalveluverkosto, joka koostuu avoimen TKI-toiminnan eri osa-alueiden osaajista. Hanke edistää myös avoimuuteen liittyvien teemojen
"Avoimen julkaisemisen jalkautuminen näkyy julkaisujen hyvänä avoimena saatavuutena. Vuonna 2017 ammattikorkeakoulujen kaikista julkaisuista avoimia oli n. $70 \%$." integrointia opetussuunnitelmiin ja pyrkii määrittelemään ja mallintamaan sitä, miten avoimuutta voidaan tuoda osaksi TKI-integroitua oppimista. Lisäksi hankkeessa sovelletaan tiedetuottajakonseptia, jotta voitaisiin parantaa osaamisen, tulosten ja tuotosten näkyvyyttä ja lisätä innovaatioekosysteemin vuorovaikutusta.

\section{Avoimet toimintamallit siirtyvät TKI-toimintaan}

voimen toimintakulttuurin pe-
rusta on strategisessa ohjauk-
sessa ja sen pohjalta laadituissa politiikoissa ja ohjeistuksissa. Tätä perustaa ovat ammattikorkeakoulut viime vuosina vahvistaneet. Tulevassa kypsyystason arvioinnissa tullaan kuitenkin kiinnittämään erityistä huomiota siihen, ovatko strategia ja ohjeistukset siirtyneet käytännön toimintaan.

Avointa julkaisupolitiikkaa on viety käytäntöön Arenen vuonna 2009 antaman Open Access -suosituksen mukaisesti ja yhteisen avoimen julkaisuarkiston Theseuksen siivittämänä. Myös rinnakkaistallentaminen on lisääntynyt viime vuosina merkittäväs- 
ti. Sitä tulee edelleen edesauttamaan ns. JUSTUs-Theseus -integraatio, jonka myötä rinnakkaistallenne voidaan julkaisutietojen syötön yhteydessä siirtää suoraan Theseukseen (Nikkanen 2019).

Avoimen julkaisemisen jalkautuminen näkyy julkaisujen hyvänä avoimena saatavuutena. Vuonna 2017 ammattikorkeakoulujen kaikista julkaisuista avoimia oli n. 70\% (Tolonen \& Marjamaa 20I8). Tieteelliset vertaisarvioidut julkaisut muodostavat keskimäärin noin Io \% kaikista julkaisuista ja niistä avoimia oli $56 \%$ vuon- na 2017 ja 6 I \% vuonna 20 I 8 (Ilva 20I9). Vielä on kuitenkin tekemistä, kun tavoitellaan avoimen tieteellisen julkaisemisen kansallisen strategian mukaista I00 \%:n avoimuutta.

Tutkimusaineistojen elinkaaren hallinnan kehittämistyö on parhaillaan käynnissä useassa ammattikorkeakoulussa. Osa ammattikorkeakouluista on rakentanut itse sopivia palveluja esimerkiksi tutkimusaineistojen kuvailua ja etsimistä varten. Osa ammattikorkeakouluista puolestaan hyödyntää tarjolla olevia kansallisia palveluja ja osallistuu aktiivisesti niiden edelleen

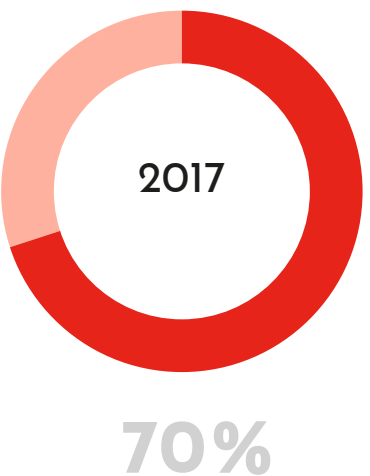

ammattikorkeakoulujen avoimet julkaisut
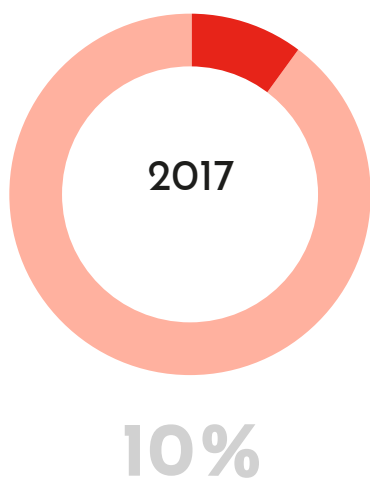

tieteellisten vertaisarvioitujen julkaisujen osuus kaikista julkaisuista

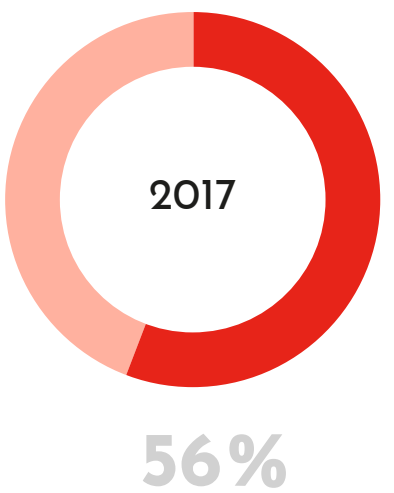

avoimet tieteelliset vertaisarvioidut julkaisut 
kehittämiseen. Molemmat tavat ovat hyviä strategisia vaihtoehtoja tutkimusaineistojen avoimuuden edistämiseksi.

TKI-toiminnan työelämäyhteistyö asettaa avoimuuden näkökulmasta omat haasteensa, joita ammattikorkeakouluissa ollaan osittain vasta tunnistamassa. Tyypillinen TKI-yhteistyömuoto on yhteiskehittäminen, jossa työelämä on usein mukana jo hankeideointivaiheesta lähtien. Yritysyhteistyöprosessit, kuten eivät niiden tuloksetkaan, voi aina olla kovin avoimia. Tällöin keskeisiä ovat esimerkiksi tietosuojaan ja omistajuuteen liittyvät kysymykset, joiden hallinta vaatii sekä soveltuvia alustoja että hyvien sopimuskäytäntöjen osaamista.

Ammattikorkeakoulukirjastot ovat olleet alusta lähtien aktiivisia avoimuuden puolesta puhujia, kouluttajia, avoimien toimintamallien kehittäjiä ja tukipalvelujen tarjoajia. Kirjastojen panos varsinkin avoimessa julkaisutoiminnassa on merkittävä. Tämän lisäksi kirjastot ovat olleet mukana myös aineistonhallinnan ja viime aikoina myös oppimisen avoimuuden kehittämisessä yhdessä organisaatioiden muiden toimijoiden kanssa. Kirjastojen tarjoama tuki on tärkeää myös jatkossa.

\section{Kohti kolmatta avoimen toimintakulttuurin kypsyystasoselvitystä}

Kevään 2019 aikana OKM on ilmoittanut suorittavansa kolmannen kypsyystasoselvityksen, joka tulee kohdistumaan korkeakoulujen ja tutki- muslaitosten ohella myös muutamiin tutkimusrahoittajiin sekä tiedeinstituutteihin. Selvityksen aluksi huhti-toukokuun aikana käydään ensin läpi organisaatioiden omat verkkosivut, minkä perusteella muodostetaan alustava kuva organisaatioiden avoimuuden kypsyystasoista

Selvityksen toisessa vaiheessa kesä-elokuussa tehdään täydentävä tiedonkeruukysely. Organisaatioilla on tällöin mahdollisuus täydentää ja korjata verkkosivuanalyysin pohjalta muodostettua tilannekuvaa. Lopullinen arviointi valmistunee syys-lokakuussa. Kypsyystasoselvityksen tavoitteena on edetä avoimena prosessina, jonka yksityiskohdat saattavat hioutua selvityksen edetessä.

\section{Avoimuuden rakennusaineet}

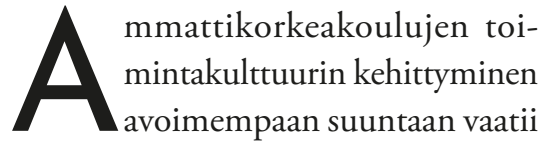
edelleen paljon työtä. Toimintakulttuurin muutoksen rakennusaineita ovat selkeä visio ja toimintasuunnitelmat sekä osaaminen, tarvittavat resurssit ja kannustimet. Selkeän vision puuttuminen luo sekaannusta ja toimintasuunnitelmien puuttuessa lähdetään helposti liikkeelle vääristä asioista. Osaamattomuus ahdistaa, kannusteiden puute herättää vastustusta ja resurssien puute turhautumista (ks. Mendéz, 2019). Kaikkien osa-alueiden on siis oltava kunnossa, jotta muutos voi tapahtua onnistuneesti. 
Kun organisaatiot nyt valmistautuvat uuteen avoimen toimintakulttuurin arviointiin myös edellä mainittujen toimintakulttuurin muutokseen tarvittavien osatekijöiden tarkastelu voi auttaa hahmottamaan oman organisaation tilaa ja avoimen toimintakulttuurin vahvistumisen tiellä mahdollisesti olevia esteitä.

\section{Lähteet:}

Avoin tiede ja tutkimus -hanke. (2015). Avoin tiede ja tutkimus Suomessa: Toimintakulttuurin avoimuus korkeakouluissa vuonna 2015 . Opetus- ja kulttuuriministeriö. Luettu osoitteesta: http://urn.fi/URN:NBN:fi-fe20I6I 2273 I 708

Ilva, J. (2019). Open Access-julkaisemisen kehitys ja tietopohja Suomessa. Bibliometriikkaseminaari 8.4.2019.

Luettu osoitteesta: http://urn.fi/URN:NBN:fi-fe20I90408 I I 363

Mendéz, E. (2019). Open Science?... Darling, we need to talk. Open Science Conference 2019 , Berlin. Luettu osoitteesta: https://www.open-science-conference.eu/ wp-content/uploads/2019/03/Eva-Mendez.pdf

NikKanen, J. (2019). Justus-Theseus käyttöönottotilaisuus 28.3.20I9. Luettu osoitteesta: https://wiki.eduuni.fi/pages/viewpage.action?pageI$\mathrm{d}=895902 \mathrm{I}$ 4\&preview=/895902 I 4/98077259/20190325_JUSTUS_Theseus.pptx

The Open Science and Research Initiative. (2016). Open Science and Research in Finland: Evaluation of Openness in the Activities of Research Organisations and Research Funding Organisations in 2016. Ministry of Education and Culture.

Luettu osoitteesta: http://urn.fi/URN:NBN:fi-fe20 I 6 I I I 829246

PäÄllysaho, S., \& Latvanen, J. (20 I 8). Avoimuuden kehittyminen suomalaisissa ammattikorkeakouluissa. Informaatiotutkimus, 37(4), i I 5- 26.

Luettu osoitteesta: https://doi.org/I0.23978/inf.774I 8

Tolonen, T. \& MarjamaA, M. (20 I 8). Ammattikorkeakoulujen julkaisujen avoimuus. Kreodi (3). Luettu osoitteesta: https://www.kreodi.fi/en/25/Artikkelit/48o/ Ammattikorkeakoulujen-julkaisujen-avoimuus.htm

\section{Tietoa kirjoittajista:}

Seliina PäÄLlysaho

tutkimuspäällikkö

Seinäjoen ammattikorkeakoulu

seliina.paallysaho@seamk.fi

ORCID: https://orcid.org/o0oo-0002-

$3554-7773$ 